\author{
Magdalena Radkowska-Walkowicz \\ m.walkowicz@uw.edu.pl \\ Instytut Etnologii i Antropologii Kulturowej \\ Uniwersytet Warszawski
}

\title{
„JAK ZACZĘŁA SIĘ TWOJA HISTORIA". NOWE TECHNOLOGIE REPRODUKCYJNE I NOWE FORMY STYGMATYZACJI
}

\author{
"How Did Your Story Begin". New Reproductive \\ Technologies and New Forms of Stigmatization
}

\begin{abstract}
Streszczenie: Punktem wyjścia mojego tekstu są ilustracje i krótki film „Jak zaczęła się twoja historia", wykonane przez Małgorzatę Kowalewską w odpowiedzi na diagnozowaną przez nią stygmatyzację i dyskryminację osób, które urodziły się dzięki zapłodnieniu pozaustrojowemu. W tekście analizuję projekt Małgosi, jak i jej wypowiedzi, jako „dziecka z in vitro”, podczas badań etnograficznych. Za jej pośrednictwem pokazuję mechanizmy stygmatyzacji i możliwe konsekwencje mocnej argumentacji przeciwników in vitro. W ich retoryce „dzieci z in vitro” stają się osobami o słabszej kondycji fizycznej, moralnej i psychicznej. Uznaję, że w ten sposób są budowane schematy poznawcze - gotowe zestawy poglądów, które niektórzy aktorzy społeczni przywłaszczają jako pewne wyjaśnienia - mogące prowadzić do naznaczania i dyskryminacji osób urodzonych dzięki in vitro i ich bliskich, w tym przede wszystkim rodziców. $Z$ jednej strony, pokażę więc narracje publiczne (i polityczne zarazem), z drugiej, ich interwencje w porządek codzienny konkretnych osób. Chcę więc prześledzić, jak polityczne pojawia się w przestrzeni prywatnej. Ważnym kontekstem dla moich rozważań jest kwestia roli Kościoła katolickiego w zarządzaniu moralnością polskich obywateli.
\end{abstract}

Słowa kluczowe: in vitro; stygmatyzacja; dyskryminacja; Kościół katolicki; dzieci.

Abstract: The text starts with presentation of illustrations and the short film How did your story begin, which Małgorzata Kowalewska prepared in response to stigmatization and discrimination of people born thanks to in vitro fertilization (IVF). In this text I analyse both Małgorzata's project and the ethnographic interviews with her as an „IVF child”. Basing on her work and statements I show the mechanism of stigmatization and possible consequences of the strong argumentation of IVF opponents. In their rhetoric, „IVF children” are presented as people who may have various physical, moral, and psychological problems. In my opinion in this way the opponents build the epistemological schemes - i.e. ready set of ideas, which some social actors internalize and treat as a proven knowledge - which can lead to stigmatization and discrimination of people born after IVF, and their parents. I show the public and political narratives and their influence on daily lives of many peo- 
ple. Thus, I scrutinize how the political appears in the private space. Moreover, the role of Catholic Church in the managing of Polish citizens' morality is the important context of my reflection.

Keywords: in vitro fertilization; stigmatization; discrimination; Catholic Church; children.

„Co możesz o mnie powiedzieć, kiedy mnie widzisz?" - pyta z ekranu ładna, młoda dziewczyna. „Mam piegi. Zielone oczy. Ciemne włosy. Uśmiecham się. Jestem dziewczyną. Czego nie możesz o mnie powiedzieć, kiedy na mnie patrzysz?" - pyta dalej. „Jakie lubię kwiaty. Co lubię jeść. Jakie mam hobby. Jakich mam przyjaciół. Co mnie bawi. A co mnie wzrusza. Jak zaczęła się moja historia". Po tych słowach widzimy zbliżenie na album ze zdjęciem kilkukomórkowego zarodka, zrobionym w trakcie procedury zapłodnienia pozaustrojowego. Jeśli się przyjrzeć, widać kartę leczenia $\mathrm{z}$ zapisem „zalecono leczenie IVF [in vitro fertilization]”. Na koniec krótkiego filmu ${ }^{1}$ przeczytamy jeszcze dwa zdania podsumowania: „Wyróżnia nas to, jacy jesteśmy, a nie, jak byliśmy poczęci. Wytykanie osób z in vitro to też dyskryminacja".

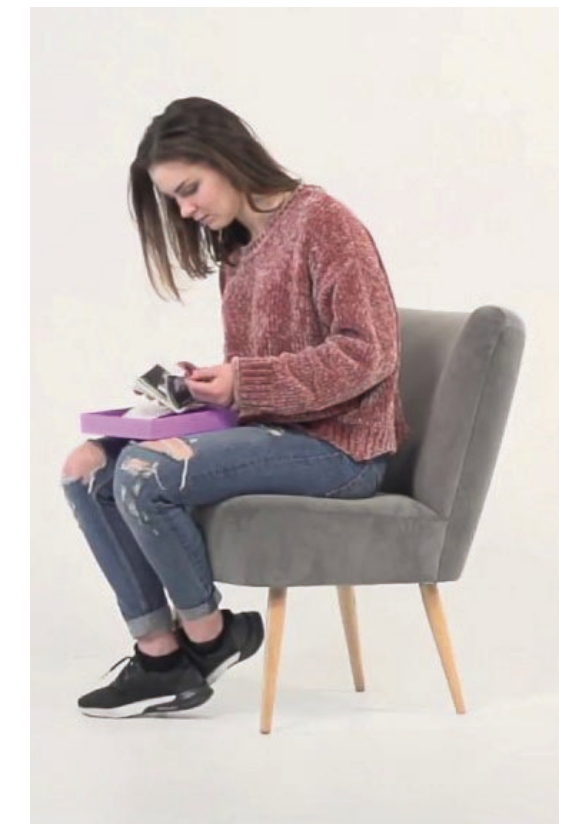

Fot.1. Kadr z filmu Jak zaczęła się twoja historia.

\footnotetext{
${ }^{1}$ Film można obejrzeć na kanale YouTube: https://www.youtube.com/watch?v=_JyN9TEILVE. Zdjęcia i montaż: Maksymilian Chałupko; pomysł: Małgorzata Kowalewska; wystąpiły: Małgorzata Kowalewska, Marta Socha, Ewa Wysocka; realizacja dzięki: Stream Online Studio i Domofonia. Wyprodukowano i opublikowano w marcu $2017 \mathrm{r}$.
} 
Film ten został zrealizowany na prośbę Interdyscyplinarnego Zespołu Badań nad Dzieciństwem UW. Małgosię, wówczas maturzystkę, autorkęi bohaterkę filmu, spotkałyśmy podczas realizacji projektu badawczego Nowe technologie reprodukcyjne - perspektywa childhood studies ${ }^{2}$. Opowiedziała nam o kilku sytuacjach w swoim życiu, w których fakt, że urodziła się dzięki technologii in vitro, niespodziewanie urósł do czegoś istotnego, wyróżniającego. Wiedząc, że interesuje się fotografią i filmem, poprosiłyśmy ją o przygotowanie projektu o jej życiu i in vitro. Małgosia wykonała kilka fotografii oraz zrealizowała dwuminutowy film - teksty, hasło i antydyskryminacyjny wydźwięk były jej pomysłem. Ten krótki projekt można traktować jako odpowiedź na pojawiające się w przestrzeni publicznej głosy bardzo ostro krytykujące technologię in vitro, a także stygmatyzujące dzieci urodzone w ten sposób i ich rodziców.

\section{In vitro $w$ Polsce}

Pierwszy w Polsce udany zabieg zapłodnienia pozaustrojowego (dalej używam rozpowszechnionego w Polsce skrótu in vitro) został przeprowadzony w 1987 roku, w Białymstoku. Dziś w naszym kraju działa ponad 40 klinik stosujących z powodzeniem tę metodę leczenia niepłodności, a populacja dzieci urodzonych dzięki tej metodzie wynosi ponad 6,5 milionów na świecie i około 30 tysięcy na terenie Polski³. Pod koniec 2007 roku wybuchła w Polsce wielka dyskusja, trwająca nieprzerwanie do dzisiaj, na temat zapłodnienia in vitro. Głównym oponentem tej technologii jest Kościół katolicki (o stosunku kościoła do in vitro zob. Szymański 2009; RadkowskaWalkowicz 2017), rozumiany jako instytucja podległa hierarchom, wydająca instrukcje i dokumenty dla wiernych i zaangażowana w życie polityczne, a nie wspólnota wiernych. Dyskusja ta ma wymiar przede wszystkim ideologiczny i polityczny, a jak zaznaczałam w innych moich tekstach (Radkowska-Walkowicz 2013; 2014; 2017), służy w dużej mierze zbieraniu kapitału politycznego, definiowanego jako zależny od Kościoła katolickiego. Jest to w znacznym stopniu spór o jego miejsce

\footnotetext{
${ }^{2}$ W skład podstawowego zespołu prowadzącego opisywane badania, oprócz autorki niniejszego tekstu, wchodzą: dr Ewa Maciejewska-Mroczek, Anna Krawczak i Maria Reimann.

${ }^{3}$ Jeśli chodzi o populację światową, są to wstępne dane przedstawione na kongresie ESHRE w 2016 roku przez Davida Adamsona. Dane dotyczące Polski są bardzo niedokładne, gdyż w Polsce nie są gromadzone, można jednak próbować obliczyć liczbę osób urodzonych dzięki in vitro, biorąc pod uwagę jedyne twarde dane, jakie tutaj są, dotyczące liczby urodzonych dzieci w ramach programu refundacyjnego in vitro w Polsce w latach 2013-2016 oraz obliczoną na ich podstawie średnią skuteczność leczenia za pomocą metody in vitro. Dziękuję Annie Krawczak za wskazanie powyższych szacunków i danych.
} 
i rolę w społeczeństwie; w tym o zachowanie jego „monopolu na moralność” (Inglis 1998), co jest ściśle związane z kontrolą nad rodziną, seksualnością, kobiecym ciałem i płodnością, a to z kolei przekłada się nie tylko na codzienne wybory moralne Polaków, ale także na państwo i jego instytucje (Mishtal 2015).

Po transformacji ustrojowej w 1989 r. polski Kościół katolicki niezwykle mocno zaczął ingerować w politykę państwa, zwłaszcza dotyczącą spraw obyczajowych i moralności, a tym samym pośrednio w codzienne życie obywateli. Naciski na wiernych i próba kontrolowania ich ciał odbywają się także bezpośrednio - jak pokazuje Joanna Mishtal w książce o prawach reprodukcyjnych w Polsce i wpływie religii na ich stanowienie oraz funkcjonowanie - podczas spowiedzi, wizyt księży w domach parafian, rekolekcji czy nauk przedmałżeńskich (Misthal 2015). „Ta wielopoziomowa infiltracja katolickiej ideologii w prywatną i publiczną przestrzeń", jak określa opisany wyżej proces antropolożka (Misthal 2015: 66), dotyczy przede wszystkim moralności, w tym zarządzania reprodukcją. W ostatnich latach debata na temat in vitro stała się w Polsce „nową debatą aborcyjną” (Chełstowska 2011: 104).

\section{Pytania i metoda}

Analiza tej debaty pokazuje jednoznacznie, że same dzieci urodzone wskutek poczęcia in vitro, choć pojawiają się w argumentacji przeciwników tej procedury, są jej uczestnikami niezwykle rzadko, a ich głos nie jest brany pod uwagę (Maciejewska-Mroczek, Radkowska-Walkowicz w druku). Biorąc pod uwagę wątpliwość wyróżniania „dzieci z in vitro” jako osobnej kategorii osób ${ }^{4}$, we wspomnianym projekcie badawczym postawiłyśmy sobie za cel zapytanie ich o stosunek do debaty publicznej na temat in vitro oraz o istotność faktu poczęcia pozaustrojowego. Interesuje nas to, czy i jak osoby, które wiedzą o tym, że zostały poczęte dzięki technologiom wspomaganego rozrodu, takim jak in vitro, włączają ten fakt w swoją narrację tożsamościową, myślenie o swoim miejscu w rodzinie. Interesują nas więc

\footnotetext{
${ }^{4}$ „Dyskursywna (nie realna) obecność w mediach dzieci urodzonych dzięki technologiom reprodukcyjnym jest jednocześnie ustanawianiem swoistej podmiotowości osób urodzonych "z in vitro«. Osoby urodzone dzięki omawianej technologii są interpelowane - by użyć sformułowania zaproponowanego przez Louisa Althussera (2006) - i niejako zawezwane przez oponentów tej technologii do istnienia, do bycia podmiotami "Z in vitro « - bez tego zawezwania byłyby "po prostu dziećmi«, "normalnymi dziećmi«. Mogą odpowiedzieć na to wezwanie przez przyjęcie jeszcze jednego wymiaru do swojej tożsamości (tożsamości rozumianej jako struktura dynamiczna, elastyczna, niejednorodna), która nawet jeśli jest naznaczona in vitro, to nie jako biologicznym faktem, lecz ideologicznym przekazem" (Maciejewska-Mroczek, Radkowska-Walkowicz 2017).
} 
znaczenia, jakie nasi rozmówcy nadają faktowi, że ich rodzice musieli skorzystać z pomocy medycyny rozrodu.

W naszych badaniach prowadziłyśmy zarówno klasyczne pogłębione wywiady etnograficzne $\mathrm{z}$ osobami urodzonymi po in vitro (także $\mathrm{z}$ ich rodzicami, rodzeństwem, dziadkami i babciami oraz lekarzami), jak i spotkania w grupach fokusowych, analizę dyskursu oraz obserwację uczestniczącą podczas różnych wydarzeń, w których brały udział osoby urodzone dzięki tej metodzie (np. „urodziny” ośrodków leczenia niepłodności, organizowane przez nie uroczystości z okazji Dnia Dziecka czy sesje fotograficzne do kalendarzy przygotowywanych przez Stowarzyszenie Leczenia Niepłodności i Wspierania Adopcji „Nasz Bocian”).

Ten tekst opieram przede wszystkim na studium przypadku. Chcę oddać głos Małgorzacie Kowalewskiej, autorce wspomnianego filmu. Przedstawię zatem jej opinie na temat in vitro i różne historie z jej życia związane z faktem, że przyszła na świat dzięki tej technologii. Uznaję bowiem, że antropologia zaangażowana na rzecz wsparcia grup marginalizowanych i stygmatyzowanych powinna poszukiwać możliwych kanałów komunikacji między tymi grupami a innymi uczestnikami kultury akademickiej i nie tylko. Jak piszą autorki wstępu do książki Antropologia wobec dyskryminacji:

Zadaniem antropologów stać się powinno nie tylko słuchanie i analizowanie głosów grup marginalizowanych, biednych, ignorowanych, ale także ich przekazywanie i upowszechnianie. Problemy grup wykluczonych, dzięki wsparciu badaczy, mogą stać się rozpoznawalne i być uwzględniane w dyskursie społeczno-politycznym (Dąbrowska, Grabowska, Kościańska 2015: 13).

Małgosia, bohaterka tego tekstu, jest osobą z wysokim kapitałem społecznym, studentką, mówi, można uznać, tym samym językiem co antropolożka, nie zachodzi więc w tym przypadku problem reprezentacji „podrzędnych”, nie chodzi tu o kwestię wyrażoną w klasycznym już tekście przez Gayatri Spivak (2011). Małgosia nie czuje się podrzędna, niewystarczająco uprawomocniona do mówienia o swoim problemie. Co więcej, miała okazję występować publicznie w obronie technologii, która pomogła jej przyjść na świat. Pojawiła się wraz ze swoją mamą w programie telewizyjnym, była bohaterką artykułu w prasie popularnej. Jednak jej głos, podobnie jak głosy innych osób urodzonych dzięki in vitro, a próbujących przemawiać w swoim imie-

\footnotetext{
${ }^{5}$ Za zgodą Małgorzaty podaję jej prawdziwe imię i nazwisko. Niniejszy tekst został przed drukiem przez nią przejrzany.
} 
niu i w swojej sprawie (są to nieliczne wystąpienia), nie jest wysłuchiwany, nie jest pożądany. „O nas się mówi, ale z nami się nie rozmawia” - powiedziała nam inna, 21-letnia uczestniczka naszych badań.

Za pośrednictwem Małgosi, jej projektu wizualnego i historii przedstawionej nam przez nią w trzech różnego rodzaju spotkaniach ${ }^{6}$, chcę wskazać na mechanizmy stygmatyzacji w polskiej debacie o in vitro. $Z$ jednej strony, pokażę narracje publiczne (i polityczne zarazem), z drugiej, ich interwencje w porządek codzienny konkretnych osób, w tym Małgosi. Chcę prześledzić, jak polityczne pojawia się w przestrzeni prywatnej.

Kontekstem dla opowiadanego studium przypadku są wspomniane badania wśród dzieci urodzonych dzięki in vitro oraz wyniki analizy wypowiedzi przeciwników tej technologii (dokładniej omówione w innych publikacjach: RadkowskaWalkowicz 2012; 2013; 2014; 2017; Korolczuk 2014), prezentowane między innymi w takich gazetach, jak „Nasz Dziennik”, „Gość Niedzielny” czy magazyn „Do Rzeczy” oraz na tak zwanych portalach katolickich (m.in. opoka.pl, fronda.pl). Chociaż krytyczne opinie wobec tej technologii są bardzo stanowcze, częste i powtarzane przez wiele mediów, trzeba brać pod uwagę, że również w głosach lekarzy zaangażowanych w procedury zapłodnienia pozaustrojowego czy w narracjach tak zwanych mediów liberalnych znajdziemy wiele mitologizacji czy uproszczeń (więcej o tym: Maciejewska Mroczek, Radkowska-Walkowicz 2018). Tu skupiam się jednak na stygmatyzacji, stereotypizacji i dążeniu do budowania schematów poznawczych, które mogą prowadzić do naznaczania i dyskryminacji pewnej grupy osób, w związku $\mathrm{z}$ tym, jeśli chodzi o reprezentacje medialne, będę przedstawiać strategie retoryczne i kryjące się za nimi poglądy jedynie przeciwników in vitro.

\section{Małgosia}

Zacznę od tego, że jestem dzieckiem poczętym metodą in-vitro. Nie odczuwam z tego powodu ani dumy, ani wstydu, gdyż wychowano mnie w myśli, że jest to rzeczą zu-

\footnotetext{
${ }^{6}$ Chodzi tu o: 1) pogłębiony wywiad etnograficzny przeprowadzony z Małgosią oraz z Małgosią i jej mamą przez Ewę Maciejewską-Mroczek; 2) zorganizowaną przez nasz zespół dyskusję - w ramach projektu Nowe technologie reprodukcyjne - perspektywa childhood studies - w której uczestniczyła Małgosia, na temat przedstawienia Bal na planecie Ziemia (w którym brała udział); 3) nienagrywane, nieformalne spotkanie z Małgosią.
} 
pełnie normalną. Z tego miejsca, chcę też podziękować rodzicom, którzy zdecydowa-

li się o mnie walczyć do końca (Gosia Kowalewska, wpis na Facebooku, 23.09.2016).

Małgosia urodziła się w 1997 r. w Warszawie. Zanim przyszła na świat, jej mama miała już za sobą kilka niepowodzeń w staraniach o dziecko i jedynym sposobem na biologiczne rodzicielstwo było dla niej skorzystanie z zabiegu in vitro. Kiedy po pierwszym transferze zarodków do macicy zobaczyła pozytywny wynik testu ciążowego, „otworzyły się niebiosa, słońce zaczęło świecić” - jak opowiadała w wywiadzie $^{7}$. Rok po urodzeniu Małgosi jej mama zdecydowała się wrócić do kliniki w celu transferu pozostałych zamrożonych zarodków. Niedługo po tym przyszła na świat siostra bohaterki tego tekstu.

O tym, że została poczęta in vitro, Małgosia wiedziała „od zawsze”: „nie pamiętam, kiedy się dowiedziałam, bo wiedziałam od... no nie wiem, jakoś tak zawsze rosłam z tym i wiedziałam, że było jakieś in vitro". Kiedy miała 12 lat pojawiła się na próbach do przygotowywanego przez Teatr Buffo spektaklu Bal na planecie Ziemia. Zagrała w nim główną rolę, obok innych dzieci urodzonych dzięki in vitro i profesjonalnych aktorów. Przedstawienie, którego premiera odbyła się w marcu 2009 r., było pierwszą zbiorową odpowiedzią środowiska skupionego wokół leczenia niepłodności metodą in vitro - lekarzy i pacjentów - na coraz częściej pojawiające się w mediach i coraz bardziej radykalne opinie dotyczące tej technologii. Bal na planecie Ziemia to opowieść o Matce Ziemi i Ojcu Słońce, którzy bardzo się kochali, ale „ich ziarenko nie chciało wykiełkować”. Dzięki pomocy czarodzieja na świecie pojawiła się dziewczynka. Cudowny czas przerwała biedronka, która nie przebierała w słowach, mówiąc: „Zgorszenie: hodowanie dzieci w szklance!” czy udając współczucie: „Jak ty będziesz żyć - taka inna, taka samotna. A gdzie twoi bracia i siostry? Wylane do rynsztoka!”. Dziewczynka była zrozpaczona, podobnie jak inne dzieci: „Mówią, że nie mamy serca, mówią, że nie mamy duszy" - śpiewały. Sprawa skończyła się ich wygraną w sądzie i zmianą poglądów biedronki (zob. Siedlecka 2009) ${ }^{8}$.

Po tym spektaklu Małgosia kilka razy pokazała się w mediach: była zapraszana do telewizji śniadaniowej i tzw. prasy kobiecej, by wraz z mamą zaświadczyć o tym, że in vitro nie oznacza wrodzonych wad i nieszczęśliwego życia.

\footnotetext{
${ }^{7}$ Wywiad przeprowadzała Ewa Maciejewska-Mroczek.

${ }^{8}$ Obszerne fragmenty spektaklu można obejrzeć tu: https://www.youtube.com/watch? $\mathrm{v}=\mathrm{K} 6-$ mq-OQdNuI\&feature=youtu.be. Spektakl został wyprodukowany przez Open Europe Art. Platforma Artystyczna na zlecenie D\&D Communication.
} 


\section{Trzydzieści sześć godzin}
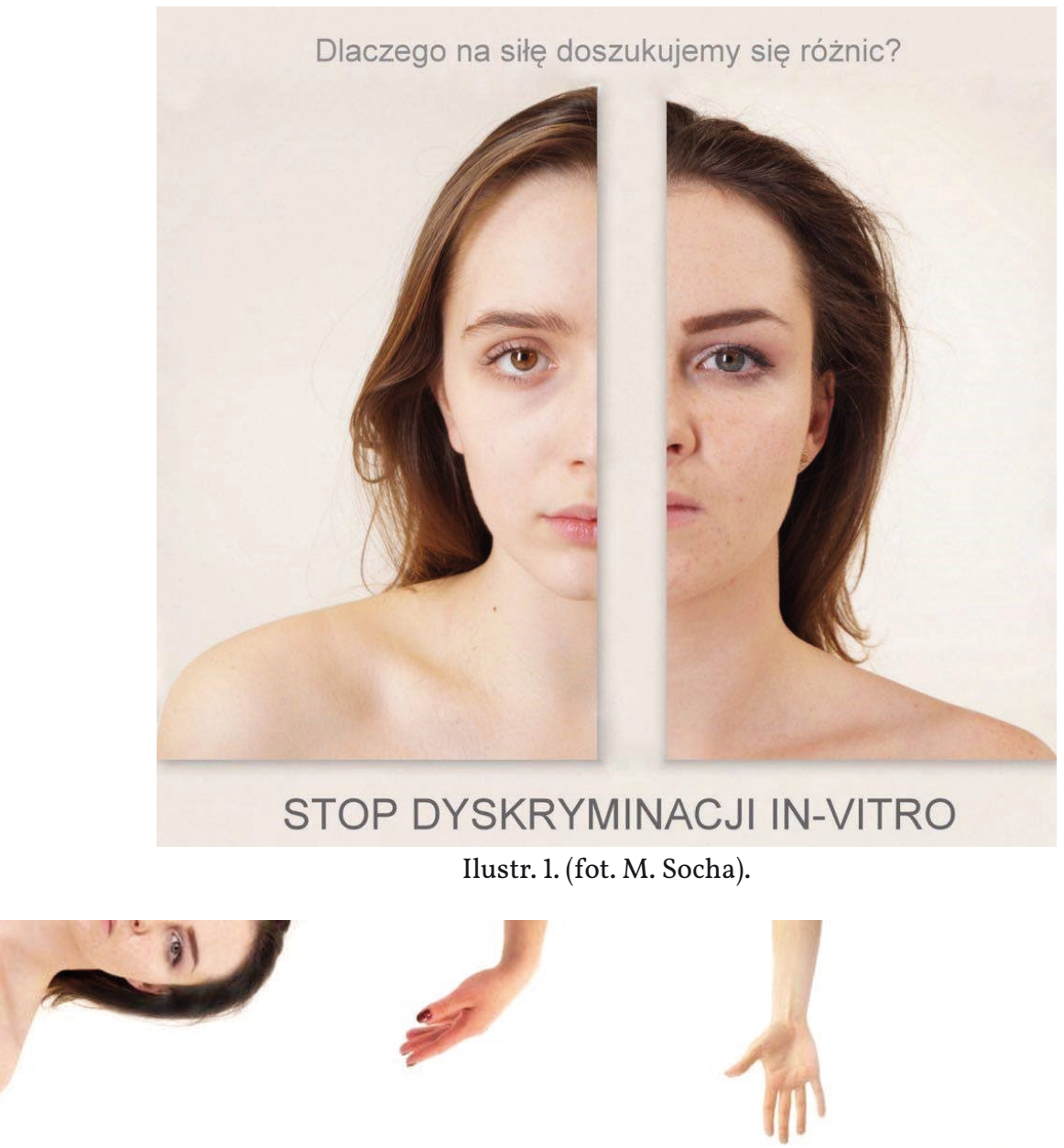

CZY POTRAFISZ WSKAZAĆ, KTÓRA Z NICH JEST „INNA" ?

STOP DYSKRYMINACJI IN VITRO
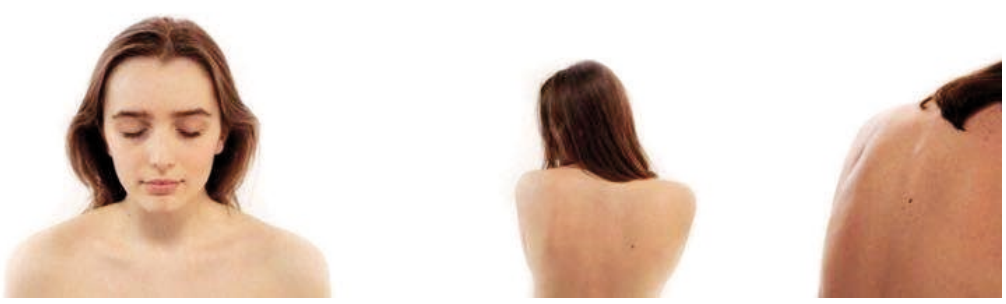

Ilustr. 2. (fot. M. Socha). 
Na pierwszej ilustracji widzimy połówki twarzy dwóch podobnych do siebie młodych kobiet i hasło: „Dlaczego na siłę doszukujemy się różnic? Stop dyskryminacji in-vitro". Na kolejnej [llustr. 2] te same dziewczyny zostały rozczłonkowane, a jej autorka proponuje zabawę w szukanie różnic. Jest to bezpośrednie nawiązanie do języka oponentów technologii in vitro, którzy w swojej argumentacji często odwołują się do różnic, jakie miałyby być między dziećmi urodzonymi po in vitro a pozostałymi. Od kiedy w Wielkiej Brytanii w 1978 na świat przyszła Louise Brown, pierwsze dziecko poczęte „na szkle”, biomedycyna zastanawia się, czy te różnice istnieją. Do dzisiaj nie daje nam jednoznacznych odpowiedzi. Są badania międzynarodowych zespołów badawczych, pracujących w paradygmacie medycyny opartej na faktach (EBM), które pokazują, że nie ma dowodów na to, że dzieci poczęte dzięki in vitro mają większą skłonność do chorób czy wad, zwłaszcza jeśli uwzględnione zostaną długość występowania niepłodności oraz wiek matki (Rimm 2011). Inne badania wskazują na niewielki wzrost prawdopodobieństwa wystąpienia niepożądanych powikłań okołoporodowych, takich jak przedwczesny poród i niska masa urodzeniowa (Harlev 2016). Nie udowodniono natomiast istnienia zwiększonego ryzyka zaburzeń emocjonalnych, behawioralnych czy psychicznych. Podobnie nie odnotowuje się zwiększonego ryzyka deficytów poznawczych czy społecznych (Bay, Mortensen and Kesmodell 2013) ${ }^{9}$. Konserwatywni aktorzy debaty medialnej często jednak wskazują na owe różnice, wyolbrzymiają je tak, by zaświadczały przeciwko technologii wspomaganego rozrodu (analiza procesu monsteryzacji dzieci z in vitro zob. Radkowska-Walkowicz 2012; 2013). Poszukuje się ich w kondycji fizycznej, psychicznej i etycznej dzieci. Mają one być słabsze, obciążone ryzykiem poważnych wad genetycznych, co może się wiązać z widocznymi stygmatami. Nasi rozmówcy najbardziej zapamiętali „bruzdę", o której w wywiadzie dla tygodnika „Do Rzeczy” mówił ks. Franciszek Longchamps de Bérier, członek Zespołu Ekspertów Konferencji Episkopatu Polski ds. Bioetycznych: „Są tacy lekarze, którzy po pierwszym spojrzeniu na twarz dziecka wiedzą, że zostało poczęte $\mathrm{z}$ in vitro. Bo ma dotykową bruzdę, która jest charakterystyczna dla pewnego zespołu wad genetycznych” (Krzyżak, Longchamps de Bérier 2013: 84). „Bruzda”, podobnie jak wymieniane przez oponentów in vitro wady genetyczne $\mathrm{e}^{10}$, które mają występować

\footnotetext{
${ }^{9}$ Więcej o zdrowiu dzieci z in vitro i wykorzystywaniu danych naukowych do wsparcia konkretnych ideologii zob. Dolińska 2009; Radkowska-Walkowicz 2012.

${ }^{10}$ Cytowany już Longchamp de Bérier dużo mówił o problemach, jakie mogą spotkać osoby urodzone dzięki in vitro: „Okazuje się, że są takie zespoły wad genetycznych, które wielokrotnie czę-
} 
częściej u osób urodzonych wskutek zapłodnienia pozaustrojowego, świetnie wpisują się w Goffmanowską teorię piętna (2005) i inne prace opisujące mechanizmy czynienia kogoś lub całej grupy ludzi obcymi, gorszymi osobami, które wymagają najpierw szczególnej refleksji i uwagi, a potem zazwyczaj wypracowania mechanizmów społecznej kontroli nad nimi.

Małgosia procesy naznaczania "dzieci z in vitro" komentuje jednoznacznie. $\mathrm{Na}$ pytanie, czy słyszała jakieś opinie w mediach na ten temat, odpowiada: „O tak. Że dzieci potwory, jakieś dzieci diabła. Że dzieci z in vitro mają bruzdy na czołach. Co to jest bruzda?". Magdalena Kołodziej, pierwsza osoba w Polsce urodzona dzięki in vitro, która także wzięła udział w naszych badaniach, w swoim liście, który był reakcją na kolejną parlamentarną debatę o leczeniu niepłodności, napisała:

Nie jestem połamana, nie mam na czole bruzdy, nie cierpię na małogłowie, w dodatku mam dwie wspaniałe córki poczęte w sposób naturalny. (...) to nie metoda zapłodnienia sprawia, że dzieci z in vitro mogą zmagać się z problemami emocjonalnymi. To Kościół Katolicki oraz wszyscy jego poplecznicy, którzy nas stygmatyzują i odsuwają od społeczeństwa (Kołodziej 2015).

Wszyscy nasi rozmówcy, urodzeni dzięki in vitro, podkreślali brak różnicy między nimi a dziećmi poczętymi bez wsparcia medycyny. Mocno zaznaczają, że są tacy sami jak ich znajomi. Jeżeli doszukiwać się różnic, to w traktowaniu przez określone głosy w mediach, ale też $w$ rozbudowanej historii sprzed porodu. Biografia naszych rozmówców zazwyczaj rozpoczyna się jeszcze przed zagnieżdżeniem jaja w ściance macicy. „Mam najwcześniejsze zdjęcie z moich znajomych” - podkreśla Małgosia, która na omawianym we wstępie filmie przygląda się jemu jako początkowi „jej historii". Często ten początek jest lokowany w czasie, kiedy rodzice walczyli o bycie, jak często mówią, „pełną rodziną”. „Niczym się nie różnimy i w przeciwieństwie do

ściej występują u dzieci z in vitro niż u tych poczętych w sposób naturalny, zwłaszcza cztery takie zespoły: Pradera-Williego, Angelmana, Silvera-Russella oraz Wiedemanna. Dziecko z zespołem Pradera-Williego może mieć na przykład opóźnienie rozwoju mowy, małogłowie, charakterystyczne cechy morfologiczne twarzy. (...) Z kolei dzieci z zespołem Angelmana charakteryzuje m.in. brak koncentracji uwagi, nadpobudliwość, kłopoty z jedzeniem, ze snem, częste ślinienie się, wysuwanie języka, itd. To są wady genetyczne. Idźmy dalej: zespół Silvera-Russella. Okazuje się, że ten zespół $\mathrm{u}$ dzieci z in vitro występuje - wedle szacunków - dziesięciokrotnie częściej. Co tu mamy: niski wzrost - u mężczyzn $150 \mathrm{~cm}$, u kobiet $140 \mathrm{~cm}$. Trudności w uczeniu się, dysleksja. W zespole Wiedemanna mamy przerost języka, przepukliny brzuszne, występowanie bruzd i dołów w płatkach uszu" (Longchamp de Bérier 2013: 84). 
niektórych możemy powiedzieć z całą pewnością, że jesteśmy wyczekani i bardzo kochani!" - napisała w swoim liście Magda Kołodziej (2015).

Małgosia za swoją mamą, która w wywiadzie także o tym mówiła, ciekawie konceptualizuje tę różnicę:

Jaka jest różnica między mną a nimi? To jest trzydzieści sześć godzin w moim przypadku. (...) ponieważ moja mama nie ma jajowodu, to jajeczko nie może samo sobie przejść do - bardzo obrazowo - macicy. No nie ma jak. Więc lekarz musi je wyjąć, złączyć z plemniczkiem i włożyć z powrotem do macicy. I po prostu ten proces trwał trzydzieści sześć godzin. I tyle. I to jest ta różnica. I wszystko, cała ciąża, wszystko przebiegało normalnie tak jak z innymi dziećmi.

Dla przeciwników in vitro te 36 godzin stanowi ogromną różnicę: „Wyciągnięcie zarodka z organizmu matki spowodowało, że nie jest on już chroniony w jej łonie. In vitro otworzyło drogę do wielu manipulacji na życiu ludzkim” - przekonuje czytelników „Gościa Niedzielnego" ksiądz Andrzej Muszala (2010). Biskup dr hab. JózefWróbel zaś w komentarzu w „Naszym Dzienniku” dotyczącym Nagrody Nobla dla Roberta G. Edwardsa mówi o problemach psychologicznych, jakie mogą wynikać z decyzji o in vitro:

Rodzice, a zwłaszcza matka, która doczekała się upragnionego dziecka, jakiś czas jest $\mathrm{z}$ tego powodu szczęśliwa. Po jakimś okresie, kiedy pierwsze emocje przeminą i spojrzy na swoje dziecko, owoc in vitro, zaczyna przeżywać traumę, bo uświadamia sobie, że wprawdzie zrealizowało się jej pragnienie, ale jest ono okupione (z reguły) kilkorgiem innych dzieci uśmierconych za jej przyzwoleniem. Pomoc udzielona takiej matce na płaszczyźnie moralnej nie rozwiązuje jej głębokich doznań psychicznych. Jeszcze większy dramat zaczyna przeżywać po jakimś czasie ta matka, która uświadamia sobie, że „w azocie” czekają zamrożone jeszcze kolejne jej dzieci, a nie jest w stanie im pomóc, nie jest w stanie ich urodzić, bo warunki zdrowotne na to jej nie pozwalają!

Szkoda, że we wszystkich dyskusjach i w samej praktyce ani lekarze, ani parlamentarzyści nie pamiętają o tych dramatach; nie widzą łez tych matek, często bardziej gorzkich od tych wyciskanych z powodu bolesnego przeżywania niepłodności... Pozostaje jeszcze pytanie: a co powiedzieć dziecku z „próbówki”, kiedy dorośnie i pozna swoją genezę, a także pewnego dnia zrozumie, że żyje tylko dlatego, bo uśmiercono jego rodzeństwo. Wmawiając mu, że nic się nie stało, albo zrobi się z niego samolubnego człowieka, albo przestanie być wrażliwe na wartości moralne, albo i ono nie poradzi sobie z samym sobą! (Wróbel 2010).

Małgosia i inni nasi rozmówcy dobrze wiedzą, co o „dzieciach z in vitro” mówią publicyści konserwatywni, prawicowi politycy i hierarchowie Kościoła katolickiego. 
Docierają do nich komentowane w mediach słowa o życiu kosztem braci i sióstr czy powtarzany opis „syndromu ocaleńca”, który ma w związku z tym ich dotyczyć (tak jak ocalali z holocaustu, dzieci z in vitro mają żyć, mimo że większość zarodków, czyli w tej retoryce „dzieci”, zostało „uśmierconych” $\left.{ }^{11}\right)$. Nie mogą zrozumieć, dlaczego historia, która w ich prywatnym życiu jest opowieścią o miłości, cierpieniu oczekiwania na dziecko i wielkim szczęściu, kiedy pojawiło się na świecie dzięki wsparciu medycyny, w publicznym dyskursie zamienia się w bajkę o złych ludziach, mordercach, wykorzystanych przez bezduszne kliniki.

\section{Historie Małgosi}

To, co polityczne, wygłoszone z ambony, mównicy parlamentarnej lub opublikowane na popularnych portalach internetowych, zostaje w różny sposób zinterpretowane i przyjęte jako pewna wiedza przez część społeczeństwa. Badania prowadzone przez CBOS pokazują, że od lat 90. XX wieku poparcie dla możliwości korzystania przez heteroseksualne pary z zapłodnienia pozaustrojowego w Polsce jest cały czas wysokie - w 2015 roku wynosiło 76 procent (CBOS 2015). Niemniej argumenty przeciwko in vitro osiadają w myśli potocznej wielu ludzi, by trafić do naszych rozmówców już nie za pośrednictwem mediów, lecz w prywatnych kontaktach z różnymi aktorami społecznymi.

Małgosia kilka razy spotkała się z sytuacją, którą odczytała jako stygmatyzującą i dyskryminująca ją, osoby jej bliskie i inne dzieci urodzone dzięki technologii wspomaganego rozrodu. Spośród osób, z którymi rozmawiałyśmy, jest wyjątkiem, jeśli chodzi o liczbę takich zdarzeń. Inni nasi rozmówcy opowiadali o pojedynczych sytuacjach, w których czuli się naznaczani przez fakt bycia „z in vitro”, lub mówili, że nie mieli tego typu problemów w codziennym życiu, ale niemal wszyscy krytykowali sposób, w jaki o in vitro mówi Kościół katolicki. Wielu z nich wskazywało, że jest to dla nich trudne i niesprawiedliwe. Wydaje się jednak, że historie Małgosi

${ }^{11}$ „Tak zwany syndrom ocaleńca został opisany na podstawie doświadczeń osób ocalonych z katastrofy, podczas gdy wszyscy ich bliscy czy znajomi zginęli. Taka osoba przeżywa silne poczucie winy, zadaje sobie pytania: dlaczego ja żyję, czy mam prawo żyć? Podobne doświadczenia przeżywają osoby, których rodzeństwo zostało abortowane. Jednak w tym przypadku to doświadczenie jest bardziej nasilone, gdyż jakaś katastrofa jest dziełem przypadku, tymczasem aborcja zależy od ludzkich decyzji. Na podobnej zasadzie dzieci poczęte drogą in vitro, przez fakt, iż w fazie embrionalnej zostały wybrane przez lekarza spośród innych dzieci, odczuwają głęboką niepewność dotyczącą swojego prawa do życia" - pisze katolicka psycholożka, cytowana w tekstach przeciwników in vitro (Rusiecka 2009). 
dobrze obrazują mechanizmy powstawania nowych obszarów stygmatyzacji, niezrozumiałych w innych państwach i w innych kontekstach politycznych.

\section{W podstawówce}

Jeszcze jako dziecko Małgosia poczuła społeczne konsekwencje wypowiadanych przez politycznych aktorów opinii na temat in vitro: „Raz w podstawówce jakiś kolega powiedział coś, ale to było tak dawno, że nawet nie pamiętam... Ogólnie byłam wtedy strasznie płaczliwa, więc chyba powiedziałam mamie, mama poszła do szkoły, żeby to wyjaśnić...". Mama Małgosi musiała przyjść do szkoły w obronie swoich córek także wtedy, kiedy ksiądz na lekcji religii z imienia i nazwiska wymienił jej młodszą córkę jako tę, która „jest z in vitro”. „Młodsza córka przestała chodzić na religię (...) [a potem] na religii ksiądz powiedział, że aborcja i in vitro to jest zło, diabeł, coś tam... i wymienił ją imiennie" - wspomina. Małgosia także zapamiętała tę sytuację:

I podobno ten ksiądz podał ją jako przykład dziecka $\mathrm{z}$ in vitro, że to jest zło, że to jest jakieś diabelstwo. Coś takiego przykrego powiedział i później inne dzieci powiedziały (...) „on mówił o tobie”, no i się zrobiła z tego straszna afera w szkole. No ale to mnie nie dotyczyło, tylko moją siostrę. (...) No i jak ona ma się czuć? Jak te dzieci później mają się czuć, kiedy im tak mówi ksiądz, który powinien być autorytetem? Kiedy mówi im, że ich koleżanka jest zła, i że to jest jej wina?

Już wtedy siostry na religię nie chodziły, bowiem, jak wspomina Małgosia: „W którymś momencie przestałyśmy, bo ksiądz przestał przychodzić tutaj po kolędzie, jak się dowiedział, że my jesteśmy z in vitro".

Jeszcze jako dziecko Małgosia musiała zmierzyć się z niewiedzą - która także przecież bywa podstawą stworzenia obrazu stereotypowego - i tłumaczyć się z tego, czego sama do końca nie rozumiała (choć dodaje: „Ogólnie to ja się tym nie przejmuję”):

Jeszcze kiedyś mi jakaś dziewczyna powiedziała (...): „Ale to ty nie masz ojca”. „Jak to nie mam ojca? Przecież go znasz..." - bo ona mieszkała naprzeciwko, była sąsiadką „Przecież go znasz”. „Ale to nie jest twój biologiczny ojciec”. Mówię: „Oczywiście, że jest biologiczny. O czym ty mówisz?" I strasznie ciężko mi było jej wyjaśnić, na czym to polega. (...) miałam, nie wiem, z dziesięć lat i sama nie wiedziałam, jak to dokładnie działa i nie umiałam jej tego wyjaśnić, ale na pewno wiedziałam, że to jest mój tata. 


\section{Słomki}

„Bycie z in vitro” okazało się także mieć znaczenie w relacjach towarzyskich Małgosi. Jeden z jej kolegów wspomniał o in vitro przy zupełnie niezwiązanej z tym okazji:

Piłam przez słomkę i on powiedział: „Jak pijesz przez słomkę, to jesteś z probówki” taki tekst powiedział. To mówię (...): „Co ty w ogóle mówisz? Co to jest, w życiu czegoś takiego nie słyszałam nawet jako żart, nawet w życiu nie słyszałam, żeby ktoś taki żart mówił...”. I mówię: „O, to troszeczkę pojechałeś”. Mówi: „A co? Przeszkadza ci coś?” Mówię: „A co ty wiesz na ten temat?”. (...) później ja mu powiedziałam, że ja jestem $z$ in vitro. Jak mnie przepraszał na kolanach, rzucił się na kolana, że on nie chciał, że on nie wiedział. Mówię: „No, dobrze, mi to nie przeszkadza, bo ja to mam dystans do tego, ale jakbyś trafił na kogoś, kto jest bardziej wrażliwy, no to może go to urazić, więc trzeba uważać na to, co się mówi”.

Potem Małgosia doda, że to nie in vitro spowodowało zakończenie tej znajomości, tylko fakt, że chłopak „był strasznie nudny”. Podobną sytuację miała w jednym ze związków:

Jego rodzice byli bardzo religijni i on przez to w pewien sposób też, ale nie do końca - bo jednak on jest w moim wieku (...). Na początku mi mówił o homoseksualistach, później zaczął o aborcji... - nie wiem, jakoś zeszła na takie tematy rozmowa - i później powiedział o in vitro. I też go tak przycisnęłam. Pytam, co on wie na ten temat (...). Powiedział, że to strasznie wpływa na gospodarkę i ekonomię, że są takie dzieci... - coś takiego dziwnego powiedział. Mówię: „A jakbyś znał taką osobę, to co?” On mówi: „Nie wiem, nie znam takiej osoby, ale na pewno bym się z kimś takim nie zadawał". Powiedziałam: „No, twoja dziewczyna jest....” To go wtedy tak zamurowało... Ale chyba on mnie tak nie przepraszał, jak ten drugi. Z tym też szybko skończyłam znajomość.

Małgosia jest silną, pewną siebie osobą, z, jak pisałam, wysokim kapitałem społecznym, umiała więc zamienić w śmiech to, że ktoś podważa wartość technologii, która pomogła jej przyjść na świat. Możemy jednak wyobrazić sobie sytuację, w której ten niewielki element biografii urósłby do znaczącego składnika tożsamości i pracowałby na rzecz wykluczania czy samowykluczania konkretnych jednostek.

\section{W samochodzie}

Kolejna historia, którą opowiedziała nam Małgosia, zdarzyła się niedawno, podczas kursu na prawo jazdy. 
Pani, która uczyła mnie do prawa jazdy [...] też była bardzo konserwatywna, bardzo religijna. Pamiętam, że ona pytała, co robiłam w weekend, a ja powiedziałam, że byłam na osiemnastce i opowiadałam jej, co tam się działo. Nie wiem, rozmawiałyśmy po prostu, a jej się strasznie nie podobało, że imprezy itd.[...)] I jakoś zaczęła á propos tych imprez coś mówić o polityce, później o aborcji, o papieżu... [...] I później powiedziała o aborcji, że to jest to samo co in vitro. Mówię: „To nie jest to samo co in vitro”. I zaczęłam się z nią kłócić. Ona mówi: „Jest, bo to jest jak zabijanie [...]. Małgosia, zgadzasz się na aborcję?" Mówię, że to zależy, w jakim przypadku, ale raczej nie, no bo każdy ma prawo żyć, prawda? [...] To mówi: „Ale to jest to samo co in vitro”. Mówię „Ale jak, to nie jest to samo, to jest absolutnie coś odwrotnego”. No i jeżeliby na tym się skończyło, no tobym się pośmiała później w domu, nieważne... Ale ona później zaczęła mówić, że moja mama to zabiła tysiące dzieci.

[Badaczka] A ty powiedziałaś jej, tak, że ty jesteś...?

Tak, później jej powiedziałam. [...] jeszcze mówiła: „O, pewnie twoim rodzicom było ciężko ciebie wychować, bo ty jesteś inna”. „Jak to!? Co to w ogóle?! Co to, jakie to ma znaczenie!?”. I wtedy... - pamiętam, że prowadziłam - a ona [...] tylko mówiła: „Prawo. Lewo. Prawo. Lewo". Ale nie zwracała mi uwagi, czy źle, czy dobrze. Ja byłam tak bardzo zdenerwowana, mimo że tak dobrze mi się wtedy prowadziło. Tak to pamiętam, po prostu chciałam się tylko skupić na jeździe, już nie chciałam z nią rozmawiać. No ale nie mogłam wyjść z tego samochodu. I później zaczęła nawiązywać do religii, że ona chciałaby widzieć jakieś objawienia Matki Boskiej, jakieś takie rzeczy i cały czas wracała do tego in vitro. Już myślałam: „Dobra, już sobie gadaj kobieto o tych jakichś duchach, jakichś dziwnych rzeczach, ale nie wracaj do tego in vitro". A ona cały czas wracała do tego. Byłam taka zła, że jak wyszłam z samochodu i przyszłam tutaj na górę, to się rozpłakałam. Bo mnie po prostu zdenerwowało [...]. Najbardziej to, że ona dała mi do zrozumienia, że moja mama zabiła tysiące dzieci. Tak mi było wtedy strasznie przykro. [...] Mama się tak zdenerwowała, zrobiła się cała czerwona, mówi: „Dawaj mi numer do tej kobiety”. Mówię: „Mamo, ale ja chciałam... Ja muszę zdać egzamin wewnętrzny jeszcze z nią i jeszcze mam trochę tych jazd, jeszcze muszę z nią przeżyć trochę". A mama, że nie, ona tak tego nie zostawi. Dałam jej numer, zadzwoniła i trochę się pokłóciły. Tamta mówi: „O, nie, to wcale nie było tak, że ona tego nie miała na myśli". Ale dawała mi do zrozumienia, że ja jestem gorsza bardzo dosadnie.

Telefoniczna interwencja mamy Małgosi, jak sama podkreślała w rozmowie z nami, doprowadziła instruktorkę do płaczu, ale nie zakończyła zupełnie tematu:

[Instruktorka] mówiła, że pewnie miałam problemy z nauką, że trudno było mnie wychować, że ja na pewno jakoś inaczej się rozwijałam. Strasznie dziwne rzeczy mówiła. W ogóle nie mogłam tego słuchać, bo to były takie kompletne bzdury, jeszcze prze- 
platała te dziwne swoje historie jakieś takie religijne, totalnie połączyła dwa tematy, które nie powinny się ze sobą łączyć, według mnie. [...] to był jedyny raz, kiedy ja się po prostu rozpłakałam - oczywiście nie przy niej - i kiedy mi było naprawdę przykro, że ktoś coś takiego powiedział, bo nie mogłam od tego uciec. Jak z kimś rozmawiam, z kolegą, to mogę powiedzieć: „Dobra, nie chcę z tobą rozmawiać, mów do mojej ręki, ja sobie odejdę". A tam nie mogłam uciec, musiałam się po prostu męczyć, taką gulę w gardle miałam, jak tam byłam.

Ta historia świetnie ilustruje przenikanie publicznych wypowiedzi do języka codzienności. Zaproponowany przez aktorów politycznych gotowy zestaw skojarzeń został przez nauczycielkę jazdy samochodem przyjęty jako prawdziwy i warty podzielenia się z młodą dziewczyną. Małgosię, jak i wielu innych naszych rozmówców, ten zestaw mocno dotyka. Po tym zdarzeniu zamieściła na swoim profilu na Facebooku post, którego fragment cytowałam powyżej:

Zwykle nie przejmuję się opinią innych na temat in-vitro. Docinki czy też głupie żarty towarzyszyły mi od dziecka, ale wszelkie komentarze puszczałam mimo uszu. Zawsze nadstawiałam drugi policzek. Tylko dlaczego musiałam to robić? Dlaczego, odkąd pamiętam musiałam wyprowadzać ludzi z błędu?

Słyszałam już, że nie mam biologicznych rodziców, że jestem „mieszanką ze szklanki”, „wyrzutkiem”, że na pewno trudno było mnie wychować, bo jestem „inna”.

Jednak tylko jedna sytuacja doprowadziła mnie do płaczu. Ktoś stwierdził, że moja mama jest mordercą. Powiedziano mi to prosto w twarz. Ja jestem silna, nie daję się sprowokować komentarzom i docinkom, które najczęściej wynikają z niewiedzy. Ale co z małymi dziećmi, które czują się gorsze i nie rozumieją dlaczego? Co jeśli te małe dzieci, któregoś dnia usłyszą w szkole, że są „potworami”, „wynalazkami”? Mi nie zaoszczędzono słuchania takich haseł.

Okrutne jest też łączenie in-vitro z aborcją. Są to zupełnie odrębne rzeczy. Dlatego apeluję o odrobinę tolerancji wobec tych, którzy zdecydowali się na tę metodę i mają już wspaniałe dzieci. Wobec tych, którzy myślą o skorzystaniu z niej z powodu zdrowia. Bo in-vitro nie jest metodą, którą ktoś wybiera z zachcianki, ale z braku innej możliwości. Każdy ma prawo do szczęścia. Każdy ma prawo do posiadania własnego potomstwa. Niektórzy potrzebują do tego pomocy, jaką niesie współczesna medycyna. Póki co jest to kwestią wyboru, czy z niej korzystać. Być może niedługo nie będzie w Polsce takiej możliwości. Rząd cofnął już pomoc finansową dla osób chcących skorzystać z owej metody. Teraz chcą ją zupełnie wycofać. Jaki jest sens? Dlaczego chcą narzucać swoją moralność? Czemu nie chcą pozostawić wyboru wolnym, myślącym, dorosłym ludziom? Nie jestem ekspertem ani w sprawie in-vitro, ani w sprawach polityki. Wiem jednak na 
pewno, że nie jestem gorsza. Wyrażam tylko swój głęboki żal do władz i innych dyskryminujących osób. Ludzie opanujcie się, bo to co się dzieje jest chore i obrzydliwe.

Warto zauważyć, że porównanie in vitro do aborcji, wprowadzenie go w pole semantyczne, gdzie mieszczą się takie słowa jak „morderstwo”, „holocaust”, „śmierć”, może być postrzegane jako celowa strategia retoryczna osób zaangażowanych w obronę wartości wiązanych z religią katolicką. "Przegraliśmy walkę o język” - pisze Agnieszka Graff (2001: 121) w imieniu polskich feministek, w kontekście polskiej dyskusji o dopuszczalności aborcji. Sukces tzw. ruchu pro-life w Polsce wynika również z przekształcenia języka debaty aborcyjnej tak, że przerwanie ciąży stało się morderstwem, a płód - nienarodzonym, poczętym dzieckiem (Matuchniak-Krasuska 2010). Podobnie dzieje się w przypadku in vitro: nie mówi się o mrożeniu zarodków, lecz mrożeniu dzieci lub trzymaniu ich w lodówkach, nie o obumieraniu ze względu na nieprawidłowy podział, lecz ich uśmiercaniu.

W tym kontekście za swoisty sukces tego ruchu można uznać to, że pojawiło się w przestrzeni publicznej skojarzenie in vitro i śmierci, co znajduje swoje miejsce w niektórych dyskusjach. Tak ukształtowany schemat poznawczy, zgodnie z tak zwanym łańcuchem dyskryminacji (Branka, Cieślikowska 2010; por. Dąbrowska, Grabowska, Kościańska 2015: 8), może prowadzić do wykluczania. Nawet jeżeli nie możemy mówić w przypadku osób urodzonych dzięki in vitro o klasycznej formie dyskryminacji, polegającej na odmawianiu pewnej wydzielonej grupie lub jednostkom do niej należącym równego traktowania (Allport 1979; Winiarska, Klaus 2011), możemy zauważyć powstawanie mechanizmów, które mogą do niej prowadzić. Jednym z nich jest stygmatyzacja, oparta na procesie naznaczania, ustanawiania inności. Na planie politycznym pomaga w zdobyciu kapitału i umożliwia sprawniejsze „zarządzanie moralnością” (Mishtal 2015), w prywatnej przestrzeni jest znakiem przywiązania do pewnego zestawu poglądów i, co za tym idzie, może służyć ustanawianiu własnej tożsamości. Jak pisze Zygmunt Bauman, „”Obcy“ ery nowoczesnej są produktami ubocznymi[...]w niekończącym się procesie wytwarzania tożsamości" (2000: 51). A jest ona kształtowana także z gotowych zestawów idei i poznawczych schematów proponowanych przez ważnych dla danej jednostki politycznych aktorów. 


\section{Podsumowanie}

Piętnowanie „dzieci z in vitro” nie musi służyć ich dyskryminacji, ma zaś prowadzić do zanegowania pozytywnego znaczenia technologii zapłodnienia pozaustrojowego i zabronienia jej stosowania. To z kolei pokazuje nam przestrzeń już wyraźnej dyskryminacji osób niepłodnych, które chcą skorzystać z tego, co oferuje im współczesna medycyna rozrodu. Oczywiście polska walka z in vitro nie ma służyć jedynie wykluczeniu pewnej technologii. Jej zadaniem jest przede wszystkim ustanowienie pewnego porządku politycznego, uczynienie kobiecego ciała podatnym na kontrolę (Radkowska-Walkowicz 2013), lepsze zarządzanie moralnością wiernych (Mishtal 2015) i narzucenie konkretnego jej modelu ogółowi obywateli. Stąd próba „skolonizowania świadomości” (Mishtal 2015: 185). Dyskusja o in vitro, podobnie jak kluczowa dla polskiej narracji o obyczajowości po 1989 roku dyskusja o aborcji, to „zakodowany dyskurs odbijający fundamentalne obawy, także te o kształt samego państwa, jego obowiązki w stosunku do społeczeństwa (i odwrotnie), zasady prawa i zakres ochrony praw i wolności obywatelskich" (Zielińska 2000: 24). Dyskusja na temat in vitro jest więc polem, na którym polityczni aktorzy negocjują narodowy kod moralny (moral code) (Mayer 1999: 3), wzorce dotyczące płci, a także warunki uczestnictwa w narodowej wspólnocie wyobrażonej(Anderson 1983; por. RadkowskaWalkowicz 2014). W polskim kontekście chodzi przede wszystkim jednak o wpływ Kościoła katolickiego i jego moralnych wskazówek na politykę, prawo i codzienne życie zwykłych ludzi; o pozycję w politycznej grze władzy i moralną rządomyślność (moral governmentality) (Mishtal 2015).

Ta polityczna ofensywa ma oczywiście swoje ofiary. Badając polską debatę na temat in vitro, możemy je wskazać. Wśród nich są dzieci urodzone dzięki tej technologii, będące przecież „cy frowymi tubylcami”, które słyszą to, co w mediach mówi się o nich, ich rodzicach, lekarzach, będących często - jak w przypadku Małgosi ${ }^{12}$ ważnymi osobami w ich życiu. „My to wszystko słyszymy, czytamy, ten cały ściek nie leci w próżnię" - mówi Agnieszka Ziółkowska (2012), najstarsza Polka urodzona dzięki tej technologii. Mogą, jak często czynią nasi rozmówcy, zaśmiać się, słysząc, że są „dziećmi Frankensteina”, ale mogą także poczuć się głęboko dotknięci porów-

\footnotetext{
${ }^{12}$ Małgosia bardzo ceni lekarza, który pomógł jej mamie zajść w ciążę w warszawskiej klinice leczenia niepłodności. Tak opowiada o wizytach tam: „Ja tam jestem gwiazdą. Ja tam przychodzę i wiszą moje zdjęcia (...) tak mówię na niego „drugi tata”, bo to jest doktor (...). To jak zawsze przychodzimy do niego, on kawy, od razu czekoladki jakieś, wychodzi do sklepu, kupuje i zawsze sobie rozmawiamy".
} 
naniem ich rodziców do morderców, a ich samych do osób ocalałych z „holocaustu nienarodzonych”. Nie rozumieją także, jak mówi Małgosia, „dlaczego przez poglądy jakichś ludzi ma się rodzić mniej dzieci i mniej osób ma prawo do szczęścia".

\section{Podziękowania}

Bardzo dziękuję Małgosi Kowalewskiej za przygotowanie projektu "Jak zaczęła się twoja historia" i podzielenie się swoimi doświadczeniami bycia „dzieckiem z in vitro”. Dziękuję także Ewie Maciejewskiej-Mroczek za pomoc przy pisaniu tekstu i pomysł na zaangażowanie Małgosi. Projekt został sfinansowany ze środków Narodowego Centrum Nauki przyznanych na podstawie decyzji nr UMO-2012/07/E/HS3/01024.

\section{Bibliografia}

Allport, G.W. (1979). The Nature of Prejudice. London: Addison-Wesley.

Anderson, B. (1983). Imagined Communities. Reflections on the Origin and Spread of Nationalism. London: Verso.

Bauman, Z. (2000). Ponowoczesność jako źródło cierpień. Warszawa: Wydawnictwo Sic!

Bay, B., Mortensen, E.L., Kesmodel, U.S. (2013). Assisted Reproduction and Child Neurodevelopmental Outcomes. A Systematic Review. Fertility and Sterility, 100 (3), 844-853; doi:10.1016/j. fertnstert.2013.05.034.

Branka, M., Cieślikowska, D. (2010). Edukacja antydyskryminacyjna. Podręcznik trenerski. Kraków: Stowarzyszenie Willa Decjusza.

CBOS (2015). Opinie o dopuszczalności zapłodnienia in vitro. Komunikat z badań. Pozyskano z http://cbos.pl/SPISKOM.POL/2015/K_096_15.PDF.

Dąbrowska, K., Grabowska, M., Kościańska, A. (2015). Wykluczenie Obcego - od groźnego stereotypu do dyskryminacji. W: K. Dąbrowska, M. Grabowska, A. Kościańska (red.), Antropologia wobec dyskryminacji (ss. 7-19). Warszawa: Wydawnictwo Uniwersytetu Warszawskiego.

Dolińska, B. (2009). Uczciwość $i$ wiarygodność nauki - odpowiedzialność za słowa w walce o dopuszczalność in vitro. Nauka, 4, 87-101.

Goffman, E. (2005). Piętno: rozważania o zranionej tożsamości (przeł. A. Dzierżyńska, J. Tokarska-Bakir). Gdańsk: Gdańskie Wydawnictwo Psychologiczne.

Graff, A. (2001). Świat bez kobiet: pleć w polskim życiu publicznym. Warszawa: Wydawnictwo W.A.B. 
Harlev, A. (2016). Is Fertility Treatment an Additional Perinatal Risk Factor in Women over 40 Years Old? Paper presented at the ESHRE Annual Meeting, Helsinki, July 4-6.

Kołodziej, M. (2015). Wstyd mi za Polskę. Newsweek, 10. Pozyskano z http://polska.newsweek. pl/in-vitro-pierwsza-polka-z-in-vitro-magdalena-kolodziej,artykuly,366582,1.html.

Korolczuk, E. (2014). Wystarczy in vitro, aby zniknęly całe narody. Analiza wybranych strategii retorycznych oponentów in vitro w Polsce. Warszawa: Fundacja Heinricha Bölla. Pozyskano z http://pl.boell.org/sites/default/files/downloads/Korolczuk_in_vitro.pdf.

Krzyżak, T., Longchamp de Bérier, F. (2013). In vitro niczego nie załatwia. Uważam Rze, luty $11-17,82-84$.

Maciejewska-Mroczek, E., Radkowska-Walkowicz, M.(w druku). „O nas się mówi, ale z nami się nie rozmawia". Dziecko $w$ kulturze wspótczesnej $i$ badaniach społeczno-kulturowych $w$ kontekście polskiej debaty na temat technologii reprodukcyjnych. Miscellanea Anthropologica et Sociologica.

Maciejewska-Mroczek, E., Radkowska-Walkowicz, M. (2018). Between Monster Child and Innocent Baby. Managing Fear and Hope in Polish Debates on In Vitro Fertilization. W: J. Ahlbeck, P. Lappalainen, K. Launis, K. Tuohela (red.), Childhood, Literature and Science: Child Figures as Fragile Subjects (ss. 184-195). Oxon, New York: Routledge.

Matuchniak-Krasuska, A. (2010). Kategorie i reguły polskiego dyskursu o aborcji. W: M. Czyżewski, K. Dunin, A. Piotrowski (red.), Cudze problemy. O ważności tego, co nieważne. Analiza dyskursu publicznego w Polsce (ss. 129-156). Warszawa: Wydawnictwa Akademickie i Profesjonalne.

Mayer, T. (1999). Gender ironies of nationalism. Setting the stage. W: T. Mayer (red.), Gender Ironies of Nationalism: Sexing the Nation (ss. 1-24). London, New York: Routledge.

Mishtal, J. (2015). The politics of morality: the church, the state, and reproductive rights in postsocialist Poland. Athens, $\mathrm{OH}$ : Ohio University Press.

Muszala, A. (2010). Ekologia człowieka (w rozmowie z Tomaszem Jaklewiczem). Gość Niedzielny, 27. Pozyskano z http://gosc.pl/doc/803390.Ekologia-czlowieka/2.

Radkowska-Walkowicz, M. (2012). The creation of 'monsters': the discourse of opposition to in vitro fertilization in Poland. Reproductive Health Matters, 20 (40), 30-37.

Radkowska-Walkowicz, M. (2013). Doświadczenie in vitro. Niepłodność i nowe technologie reprodukcyjne w perspektywie antropologicznej. Warszawa: Wydawnictwo Uniwersytetu Warszawskiego.

Radkowska-Walkowicz, M. (2014). Frozen Children and Despaired Embryos in the 'New' Post Communist State: Debate on IVF in the Context of Poland's Transition. European Journal of Women's Studies, 21 ( 4), 399-414. 
Radkowska-Walkowicz, M. (2017). How the Political Becomes Private: In Vitro Fertilization and the Catholic Church in Poland. Journal of Religion and Health, https://doi.org/10.1007/s10943017-0480-3.

Rimm, A.A., Katayama, A.C., Katayama, P. (2011). A meta-analysis of the impact of IVF and ICSI on major malformations after adjusting for the effect of subfertility. Journal of Assisted Reproduction and Genetics, 28 (8), 699-705.

Rusiecka, B. (2009). Dziecko za cenę miłości (w rozmowie z Małgorzatą Jędrzejczyk). Nasz Dziennik. Pozyskano z http://archiwum.dlapolski.pl/rodzina/Komu-zalezy-na-in-vitro-n235. html; dostęp: 10.04.2013.

Siedlecka, E. (2009). Teatr in vitro z happy Endem. Gazeta Wyborcza. Pozyskano z http://wyborcza.pl/1,76842,6354392,Teatr_in_vitro_z_happy_endem.html.

Spivak, G. (2011). Czy podporządkowani inni mogą przemówić? (przeł. E. Majewska). Krytyka Polityczna, 24-25, 196-239.

Winiarska, A., Klaus, W. (2011). Dyskryminacja i nierówne traktowanie jako zjawisko społeczno-kulturowe. Studia BAS, 2 (26), 9-40.

Wróbel, J.(2010). Na marginesie dyskusji nad Noblem za in vitro. Nasz Dziennik. Pozyskano z http:// www.radiomaryja.pl/bez-kategorii/na-marginesie-dyskusji-nad-noblem-za-in-vitro.

Zielińska, E. (2000). Between ideology. W: G. Kligman(red.), Reproducing Gender. Politics, Publics, and Everyday Life after Socialism (ss. 23-58). Princeton, NJ: Princeton University Press.

Ziółkowska, A. (2012). Niepokalanie poczęta. Agnieszka, najstarsze w Polsce dziecko z in vitro. Gazeta Wyborcza. Pozyskano z http://www.wysokieobcasy.pl/wysokie-obcasy/1,53662,122 00284,Niepokalanie_poczeta_Agnieszka_najstarsze_w_Polsce.html. 
